TARNOWSKIE STUDIA TEOLOGICZNE 35 (2016) NR 2, S. 5-25

http://dx.doi.org/10.15633/tst.2102

ks. Henryk Szmulewicz ${ }^{1}$

UNIWERSYTET PAPIESKI JANA PAWŁA II W KRAKOWIE

\title{
Współczesny „przymus niewiary” wyzwaniem dla ekumenizmu
}

W pięćdziesiątą rocznicę zakończenia Soboru Watykańskiego II odbyło się wiele podniosłych uroczystości i wydarzeń o charakterze teologiczno-duszpasterskim. Była to okazja do przypomnienia soborowego nauczania w nowym kontekście ewangelizacji. W ramach wspomnianych obchodów nie zabrakło konferencji naukowych poświęconych analizie poszczególnych dokumentów soborowych, wśród nich deklaracji Dignitatis humanae ${ }^{2}$. Dla przykładu, w Domu Arcybiskupów Warszawskich (28 października 2015 roku) miało miejsce sympozjum pt. Kościót - wolność - pluralizm. Pót wieku od zakończenia II Soboru Watykańskiego. Podkreślono, że szczególnym wyzwaniem, przed którym stoi dzisiaj Kościół, jest ateizm i laicyzacja ${ }^{3}$. Ta sama troska o rozwój i obronę wiary na fundamencie niezbywalnego prawa osoby ludzkiej do wolności religijnej towarzyszyła Iv Międzynarodowej Konferencji Ekumeniczno-Prawnej pt. Wolność religijna dzisiaj (Brenna, 16-17 kwietnia 2015 roku) ${ }^{4}$.

Punktem wyjścia dla rocznicowych spotkań i dyskusji było przekonanie o ponadczasowym charakterze nauki soborowej, ukazującej wiarę jako osobową decyzję, która nie może być w jakikolwiek sposób wymuszana ani też

1 Henryk Szmulewicz - kapłan diecezji tarnowskiej, profesor tytularny nauk teologicznych. Kierownik katedry teologii fundamentalnej i ekumenizmu w Wydziale Teologicznym Sekcja w Tarnowie Uniwersytetu Papieskiego Jana Pawła II w Krakowie.

2 Sobór Watykański Drugi, Deklaracja o wolności religijnej Dignitatis humanae, w: Sobór Watykański Drugi, Konstytucje, dekrety, deklaracje. Tekst łacińsko-polski, Paris 1967, s. 401-419 [dalej: dekl. Dignitatis humanae].

3 Por. Serce praw człowieka - konferencja o wolności religijnej w 5o. rocznicę zakończenia Soboru, „Wiadomości KAI” $2015 \mathrm{nr}$ 45, s. 7.

4 Por. http://www.ekumenizmiprawo.pl/iv-miedzynarodowa-konferencja-ekumeniczno-prawna. 
zabraniana. Oto wymowny w tym względzie fragment Dignitatis humanae: „Wszyscy ludzie powinni być wolni od przymusu ze strony czy to poszczególnych ludzi, czy to zbiorowisk społecznych i jakiejkolwiek władzy ludzkiej tak, aby w sprawach religijnych nikogo nie przymuszano do działania wbrew jego sumieniu ani nie przeszkadzano mu w działaniu według swego sumienia prywatnym i publicznym, indywidualnym lub w łączności z innymi, byle w godziwym zakresie”. W świetle nauczania soborowego „z istotą wiary jest jak najpełniej zgodne, aby w sprawach religijnych wykluczony był jakikolwiek rodzaj przymusu ze strony ludzi”' .

„Wolność religijna” oznacza zatem, że nikt nie może być przymuszany ani do wiary, ani do niewiary. Chociaż jest to zasada oczywista, wielokrotnie w przeszłości, ale także we współczesnym świecie, była i bywa naruszana i lekceważona. Co więcej, metody nieuprawnionego przymusu wydają się coraz bardziej subtelne i nieuchwytne. Okazuje się, że nawet wtedy, gdy ktoś - np. w środkach masowego przekazu - apeluje o nieprzymuszanie do wiary, może to być w gruncie rzeczy dobrze przemyślana taktyka zmierzająca do promowania niewiary.

Czy można jednak udowodnić, że w takim przypadku mamy do czynienia $\mathrm{z}$ niedopuszczalną manipulacją $\mathrm{w}$ sferze wiary i religii? Jak wykazać, że walcząc o wolność religijną, wiele osób sprzyja środowiskom popierającym niewiarę? Przede wszystkim należy pamiętać o całej psychologicznosocjologicznej złożoności całego zagadnienia. Dlatego nie wolno „z góry” przypisywać komuś złych intencji. Jednak równie naganna byłaby postawa naiwnego optymizmu zakładająca, że każdy, kto opowiada się „za” wolnością religijną, jest obiektywny w ocenie wartości wiary. Już św. Piotr ostrzegał pierwszych chrześcijan, aby byli czujni i roztropni, wyzbywając się naiwnego sposobu postrzegania siebie i innych. Jedynie zachowanie realizmu w codziennym życiu jest drogą, na której można rozpoznać pojawiające się niebezpieczeństwa: „Bądźcie trzeźwi! Czuwajcie! Przeciwnik wasz, diabeł, jak lew ryczący krąży, szukając kogo pożreć. Mocni w wierze przeciwstawcie się jemu! Wiecie, że te same cierpienia ponoszą wasi bracia na świecie” $\left(1 \mathrm{P}_{5}, 8-9\right)^{7}$.

\footnotetext{
Sobór Watykański II, dekl. Dignitatis humanae, 2, s. 403-405.

Sobór Watykański II, dekl. Dignitatis humanae, 10, s. 413.

7 „Choroby współczesnego świata oraz Kościoła nie powinny stanowić wymówki, by zmniejszyć nasze zaangażowanie i nasz zapał. Traktujmy je jako wyzwania, by wzrastać. [...]
} 
W obliczu błędnych interpretacji wolności religijnej nieodzowna jest zdecydowana obrona wartości i sensu wiary. Chodzi m.in. o wspólny głos o charakterze ekumenicznym. Pomimo różnic, jakie wciąż istnieją w ramach chrześcijaństwa, wszyscy uczniowie Chrystusa winni jednoznacznie opowiadać się za wolnością religijną, dając jednocześnie czytelne świadectwo o wierze jako bezcennym skarbie, otrzymanym od Boga (por. Mt 13, 44-46). $\mathrm{W}$ niniejszym studium zwrócimy uwagę na potrzebę takiego świadectwa. Ukażemy, że dialog ekumeniczny stoi wobec konieczności obrony wiary przed jawnym lub ukrytym łamaniem zasady wolności religijnej.

\section{„Przymus niewiary”}

W wielu dokumentach Kościoła oraz we współczesnej refleksji teologicznej znajdujemy głębokie przekonanie co do rozumności i dobrowolności aktu wiary. Przypomina się, że pod żadnym pozorem nie wolno nikogo przymuszać do jej przyjęcia i wyznawania ${ }^{8}$. Zasada wolności religijnej ma także i tę implikację, że wyklucza przymuszanie do przyjęcia niewiary, czyli - inaczej mówiąc - zakazuje „przymusu niewiary”.

Problem łamania zasady wolności religijnej poprzez przymuszanie do niewiary podjął Jan Paweł II m.in. w liście skierowanym do sygnatariuszy Aktu Końcowego Konferencji Bezpieczeństwa i Współpracy w Helsin-

Nawet jeśli doświadczamy bólu z powodu nędzy naszej epoki i dalecy jesteśmy od naiwnego optymizmu, większy realizm nie powinien oznaczać mniejszej ufności do Ducha ani mniejszej hojności" (Franciszek, Adhortacja apostolska Evangelii gaudium, Kraków, b.d.w., 84, s. 47-48).

8 Por. Jan Paweł II, Prezbiter pasterzem wspólnoty, w: Jan Paweł II, Wierzę w Kościół - jeden, święty, powszechny i apostolski, Libreria Editrice Vaticana, 1996, s. 285-286; Benedykt xVI, Wiara, rozum i uniwersytet - wspomnienia i refleksje. Wykład na uniwersytecie, 12.09.2006 - Ratyzbona, „L'Osservatore Romano” 2006 nr 11, s. 26; Benedykt xvi, Niepokalana Matka pielgrzymującego Kościoła. Homilia w uroczystość Niepokalanego Poczęcia Najświętszej Maryi Panny, 8.12.2005, „L'Osservatore Romano” 2006 nr 2, s. 44; Benedykt Xvi, Świat potrzebuje Zbawiciela, który narodził się dla wszystkich. Bożonarodzeniowe orędzie Urbi et Orbi, 25.12.2006, "L'Osservatore Romano” 2007 nr 2, s. 47; Benedykt xvi, Jedność Boga tworzy jedność Kościoła (Św. Paweł pierwszym teologiem). Audiencja generalna, 15.10.2008, „L'Osservatore Romano” $2008 \mathrm{nr}$ 12, s. 55; Benedykt xVI, Afryka jest kontynentem nadziei. Msza św. z okazji przekazania Instrumentum laboris II Specjalnego Zgromadzenia Synodu Biskupów poświęconego Afryce, 19.03.2009, „L'Osservatore Romano” 2009 nr 5, s. 31; Międzynarodowa Komisja Teologiczna, Moralność chrześcijańska i jej normy (1974), w: Międzynarodowa Komisja Teologiczna, Od wiary do teologii. Dokumenty Międzynarodowej Komisji Teologicznej (1969-1996), red. J. Królikowski, Tarnów 2000, s. 35. 
kach (rok 1980). Przypomina w nim o konieczności obrony wolności „od nacisku na płaszczyźnie osobistej, obywatelskiej lub społecznej, który zmusza do spełniania czynów sprzecznych z własną wiarą, oraz (obrony) wolności od poddawania określonemu rodzajowi wychowania lub przymusu należenia do grup lub stowarzyszeń, których zasady sprzeczne są z własnymi przekonaniami religijnymi osób"9.

W tym samym duchu Konferencja Episkopatu Polski wielokrotnie apelowała o zmianę polityki społecznej wobec ludzi wierzących, jeśli przymusza się ich do wyboru drogi, która jest sprzeczna z ich wiarą. Ponieważ zagrożenie przymusem niewiary było realne, pasterze Kościoła w Polsce zwrócili się szczególnie do rodziców ${ }^{10}$.

$\mathrm{W}$ innym $\mathrm{z}$ listów pasterskich czytamy: „Ruch laicyzacji jest u nas działaniem zorganizowanym, zmierzającym do przyspieszenia procesu zeświecczenia i kierowania nim. Jest on ruchem politycznym, gdyż objęty jest planowaniem politycznym, kierowany przez instancje polityczne, a wspierany i egzekwowany środkami administracyjnymi. Jest ruchem pedagogicznym, bo zmierza do wychowania przede wszystkim tych, którzy wychowują (rodziców i nauczycieli) lub są wychowywani (dzieci i młodzież). Jest ruchem totalitarnym, bo dąży do objęcia swym wpływem wszelkich objawów życia społecznego, rodzinnego i osobistego i wyłączenia z nich wszelkich sądów i ocen opartych na religii. Jest ruchem niepozostawiającym możliwości wyboru"”. Jakich argumentów używają zwolennicy niewiary? Aby zachęcić czy wręcz przymusić osobę wierzącą - zwłaszcza spośród dzieci i młodzieży - do porzucenia wiary, ukazuje się niewiarę jako rozwiązanie wartościowsze, lepsze, mądrzejsze itp. Udowadnia się, że „wiara” jest porażką, „niewiara” zaś sukcesem. Tworzy się więc swoistą „teologię sukcesu”, opartą na dyskredytacji wiary, co w konsekwencji prowadzi do tego, że „szeroki zasięg zjawiska niewiary nadaje w oczach wielu wartość racjonalną ich indyferentyzmowi religijnemu"12.

9 Jan Paweł II, List [Dokument] L'Eglise catholique o wolności religijnej skierowany do sygnatariuszy Aktu Końcowego Konferencji Bezpieczeństwa i Współpracy w Helsinkach (01.09.1980), w: Jan Paweł II, Wybór listów Ojca Świętego Jana Pawła II, t. 1, Kraków 1997, s. 35.

${ }^{10}$ Por. Orędzie Episkopatu Polski, Do rodziców katolickich, w: Listy pasterskie Episkopatu Polski 1945-1974, Paris 1975, s. 179.

${ }^{11}$ Konferencja Episkopatu Polski, Współczesna laicyzacja, w: Listy pasterskie Episkopatu Polski 1945-1974, s. 263.

${ }^{12}$ Ch. Duquoc, Teologia a życie wewnętrzne, Warszawa 1969, s. 538. 
W sposób atrakcyjny i pozornie niewinny dąży się do tego, aby przymusić ludzi wierzących do jak najszybszego porzucenia wymogów stawianych im przez wiarę, na rzecz „prawdziwego sukcesu” - bogactwa, kariery, postępu itp. Aby ten cel osiągnąć, stosuje się - na wzór metod promowanych przez sekty - „długofalowy wpływ na umysły ludzkie”'13. Jednocześnie „udowadnia się", że wrogiem wolności, czyli przykładem przymuszania ludzi w kwestiach wiary, jest... Kościół. Nie jest on bowiem wspólnotą o charakterze nadprzyrodzonym, lecz co najwyższej organizacją o charakterze dobroczynnym. Wbrew temu, co sam o sobie mówi, realizuje (ukryte) doczesne interesy, domagając się posłuszeństwa, aby w ten sposób „panować” na swoimi wyznawcami ${ }^{14}$.

Wobec tego rodzaju interpretacji nie jest łatwo o zachowanie klimatu rzeczowej dyskusji. Jednak nadziei poważnego dialogu nie można porzucać, gdyż wolność aktu wiary to nie sprawa błaha i nieważna, lecz najbardziej fundamentalna i podstawowa. Kościół stara się dotrzeć ze swoim nauczaniem do mentalności współczesnego człowieka $\mathrm{z}$ argumentacją, według której „nikogo nie wolno przymuszać do wiary [...]. W ciągu swych długich dziejów, mimo ucisku i prześladowań Kościół stwierdzał, że każdy ma prawo swobodnie wyznawać swoją wiarę. Nikomu nie wolno przeszkadzać, by ją wyznawał; ani nikogo zmuszać, by działał przeciw własnemu sumieniu religijnemu"15.

${ }_{13}$ A. Siemieniewski, Ruch New Age wśród nowych zjawisk religijnych, w: Postawy duchowe wobec Boga, Kościoła i człowieka, red. M. Chmielewski, Lublin 1995, s. 146.

${ }^{14}$ Jan Paweł II wielokrotnie wyrażał smutek z powodu częstego dzisiaj traktowania całego posłannictwa Kościoła, jak i jego działalności misyjnej w kategorii przymusu i manipulacji: „Niektórzy dopatrywali się w działalności misyjnej próby narzucenia innym własnych przekonań i wyborów, co stoi w sprzeczności z pewną koncepcją współczesności, traktującą absolutną wolność myśli i osobistego sumienia jako trwałą zdobycz" (Jan Paweł II, Cel misyjnej działalności, w: Jan Paweł II, Wierzę w Kościót - jeden, święty, powszechny i apostolski, Libreria Editrice Vaticana, 1996, s. 581).

${ }_{15}$ Paweł vi, Świadectwo życia chrześcijańskiego, w: Będziecie mi świadkami. Paweł vi przemawia do ludzi świeckich, red. E. Weron, Poznań-Warszawa 1975, s. 213. „Dwa tysiące lat temu w zbawczej misji Jezusa Chrystusa Bóg włączył się w sposób szczególny w dzieje ludzkości, by po ścieżkach czasu prowadzić nas ku zjednoczeniu ze Sobą. Nie narzuca On jednak swych Boskich rozwiązań w sposób, który wykluczałby współdziałanie człowieka. Orędzie o zbawieniu skierowane jest zawsze do człowieka jako istoty wolnej. Chrystus formując Apostołów i swoich uczniów, przedkłada im naukę popartą własnym życiem. Oczekuje jednak dobrowolnej akceptacji i przyjęcia, gdy pyta w decydującej chwili: «Czy i wy chcecie odejść?» $(J 6,67)$. Ewangelia zaświadcza, że wielu «przychodziło i odchodziło» od Jezusa (Mk 6, 31). On zaś nie 
Apel o przestrzeganie zasady wolności religijnej Kościół w pierwszym rzędzie odnosi do samego siebie. Wie, że pokusa przymuszania w kwestiach wiary nie była obca już pierwszym gminom chrześcijańskim. Święty Piotr pisze: „Starszych, którzy są wśród was, proszę, ja również starszy, a przy tym świadek Chrystusowych cierpień oraz uczestnik tej chwały, która ma się objawić: paście stado Boże, które jest przy was, strzegąc go nie pod przymusem, ale z własnej woli, jak Bóg chce; nie ze względu na niegodziwe zyski, ale $\mathrm{z}$ oddaniem; i nie jak ci, którzy ciemiężą gminy, ale jako żywe przykłady dla stada" (1 P 5, 1-3).

W ciągu wieków dochodziło, niestety, do sytuacji, w których „strona chrześcijańska" nie przestrzegała zasad przez siebie głoszonych. Zamiast bronić wolności religijnej w ramach ewangelizacji, podejmowane były działania, które w gruncie rzeczy oznaczały antyświadectwo i zgorszenie. Jan Paweł II podczas obchodów Wielkiego Jubileuszu Roku 2000 wspominał o „wszystkich tych sytuacjach z przeszłości, w których chrześcijanie oddalili się od ducha Chrystusa i od Jego Ewangelii i zamiast dać świadectwo życia inspirowanego wartościami wiary, ukazali światu przykłady myślenia i działania, będące w istocie źródłem antyświadectwa i zgorszenia"16.

Warto w tym miejscu dodać, że negatywna ocena przymusu nie oznacza rezygnacji ze stawiania wymagań: „Należy unikać przymusu, autorytatywnego stylu, narzucania, co wcale nie jest równoznaczne z zarzuceniem wymagań. Chrystus potrafił jedno z drugim pogodzić. [...] Wymagania są konsekwencją decyzji bycia uczniem Chrystusa, kroczenia za Nim" ${ }^{17}$. Kościół, strzegąc w imieniu Chrystusa prawdy objawionej oraz „wykluczając nietolerancję i przymus w stosunku do innych, nie uwalnia więc wiernych od obowiązku trwania przy prawdzie. Prawda ta nie pochodzi od ludzi, ale

przymuszał nikogo do pozostania, jedynie wzywał wszystkich do przyjęcia Jego nauki” (Konferencja Episkopatu Polski, Orędzie biskupów polskich o potrzebie dialogu i tolerancji w warunkach budowy demokracji, Tarnów 1993, s. 10).

${ }^{16}$ Jan Paweł II, List apostolski Tertio millennio adveniente do biskupów, duchowieństwa i wiernych w związku z przygotowaniem do Jubileuszu Roku 200o, Wrocław 1998, s. 40.

${ }_{17}$ T. Panuś, Czynniki wplywające na efektywną katechizację młodzieży, w: Katechizować dzisiaj. Problemy i wyzwania, red. J. Stala, Kielce 2004, s. 236. „Wiara ma być dobrowolna, nikogo do niej Chrystus nie przymusza. Jest ona bowiem dziełem zarówno łaski Bożej, jak i wolnej woli człowieka, i dlatego Chrystus wyrzuca brak wiary [...]. Wyrzuca miastom brak pokuty, płynącej z wiary" (R. Kostecki, Tajemnica współżycia z Bogiem. Zagadnienie cnót teologicznych wiary, nadziei i mitości, Kraków 1983, s. 30). 
została ludziom przekazana od Boga przez Jezusa Chrystusa. Nie godzi się jej wypaczać, obcinać, naciągać do własnych upodobań, ale trzeba być jej wiernym, tzn. poznać ją i przyjąć w całości”18.

Zrozumieli to do głębi ci, którzy swoją wierność Ewangelii przypieczętowali śmiercią: „Historia może nam podać bardzo wiele konkretnych przykładów, dla jakich racji męczennicy oddawali swe życie. Nakłaniani czy przymuszani do jakiegokolwiek czynu niezgodnego z którymkolwiek przykazaniem - jeśli sprzeciwiali się temu i z tej racji ponosili śmierć, stawali się męczennikami. [...] Męczeństwo jest świadectwem prawdziwości wiary, a przez to najskuteczniejszym szerzeniem wiary, najlepszą obroną, podtrzymywaniem słabych we wierze i równocześnie najlepszym środkiem na wyleczenie społeczeństwa $\mathrm{z}$ niewiary" ${ }^{\prime 19}$.

Współczesne nauczanie Kościoła i refleksja teologów wykazują zatem szczególną wrażliwość w kwestii dobrowolności aktu wiary ${ }^{20}$. Broniąc jej, negatywnie ocenia się nie tylko wszelkie próby przymuszania do wiary, ale także manipulację, zmierzającą do rozpowszechniania niewiary. Chodzi bowiem zarówno o naciski przychodzące od zewnątrz - „od wrogów nakłaniających do niewiary" ${ }^{21}$, jak i o przymus wewnętrzny. Obie formy przymusu należy odrzucić jako niezgodne z orędziem Ewangelii, gdyż „wszystkie zachęty Chrystusa Pana zmierzające do tego, by pobudzić do wiary lub ją wzmocnić, a także wpływ delikatny wywierany przezeń na wolę słuchaczy świadczy, że w mocy człowieka leży wiarę przyjąć lub ją odrzucić (por. Mk 6, 1-6; J 5, 44-47)"22.

${ }_{18}$ S. Olejnik, Dar, wezwanie, odpowiedź. Teologia moralna, t. 4: Podstawowe ukierunkowanie życia chrześcijańskiego, Warszawa 1989, s. 93.

19 R. Kostecki, Tajemnica współżycia z Bogiem..., s. 93.

${ }^{20}$ „Dialog zbawienia jest wolny od przymusu fizycznego. Kościół ofiarowuje Boże orędzie zbawienia, respektując wolność osobistą człowieka. Zależność wiary od wolnej woli potwierdza psychologia religii i codzienna obserwacja, pokazując, jak olbrzymią rolę w całym procesie wiary odgrywają czynniki emocjonalne i wolitywne" (J. Krasiński, Przez wiarę i nadzieję ku cywilizacji miłości, Sandomierz 1987, s. 17).

${ }^{21}$ R. Kostecki, Tajemnica współżycia z Bogiem..., s. 109.

${ }^{22}$ W. Granat, Dogmatyka katolicka, t. 6: Teologiczna wiara, nadzieja i miłość, Lublin 1960, S. 204. 


\section{Dobrowolność wiary podstawą dialogu ekumenicznego}

Bóg Trójjedyny objawił się człowiekowi jako Stworzyciel i Zbawiciel. W odpowiedzi odczekuje dobrowolnej decyzji wiary, gdyż bez niej „nie można podobać się Bogu. Przystępujący do Boga musi uwierzyć, że [Bóg] jest i że wynagradza tych, którzy Go szukają" (Hbr 11, 6) ${ }^{23}$. Credo recytowane zarówno przez katolików, jak i prawosławnych, protestantów i anglikanów, wyraża wspólną wiarę w „istnienie Syna w relacji do Ojca; stwierdza Jego równość z Ojcem w jednej rzeczywistości Boga oraz wyznaje, że Syn Boży stał się człowiekiem, gdy mocą Ducha Świętego przyjął «ciało» z Maryi Dziewicy. Jezus nie stał się Synem dopiero przez swe zmartwychwstanie, lecz jest Nim od początku swego ziemskiego życia, ponieważ zawsze już był Synem Boga istniejącego odwiecznie"24.

Wiara jest tym, co łączy, a jednocześnie tym, co dzieli chrześcijan. Aby więc wspólna - ekumeniczna - obrona wolności religijnej była we współczesnym świecie wiarygodna, trzeba pamiętać o blaskach i cieniach relacji między chrześcijanami. Jeremiasz Anchimiuk (to głos prawosławia) wzywa, aby sięgać do tego, co już się wydarzyło - dla uniknięcia błędów w interpretacji wiary, jej przymiotów, źródeł i celu. Różnice pochodzące „z przeszłości” wciąż są bowiem zarzewiem goryczy ${ }^{25}$.

${ }^{23}$ „Łaska Chrystusa w żadnym wypadku nie narusza naszej wolności, gdy odpowiada ona zmysłowi prawdy i dobra, jaki Bóg złożył w sercu człowieka. Przeciwnie, doświadczenie chrześcijańskie, zwłaszcza doświadczenie modlitwy, świadczy o tym, że im bardziej jesteśmy ulegli wobec poruszeń łaski, tym bardziej wzrasta nasza wewnętrzna wolność i nasza pewność zarówno wobec trudności, jak wobec nacisków i przymusu ze strony świata zewnętrznego" ( $\mathrm{Ka}$ techizm Kościoła Katolickiego, Poznań 1994, 1742).

${ }^{24}$ P. Jaskóła, Bóg dla nas. Ekumeniczno-dogmatyczne studium chrystologii Johna Arthura Thomasa Robinsona, Lublin 1986, s. 9.

${ }^{25}$ „Pełna entuzjazmu skłonność do kierowania się wyłącznie ku świetlanej przyszłości bez uwzględnienia doświadczeń przeszłości i realiów dnia dzisiejszego prowadziła zawsze do katastrofy" (J. Anchimiuk, Problem ekumenizmu dzisiaj, w: Ku chrześcijaństwu jutra. Wprowadzenie do ekumenizmu, red. W. Hryniewicz, J. S. Gajek, S. J. Koza, Lublin 1997, s. 15). Jak przypomina Wolfgang Beinert, także „pośród sporów okresu Reformacji [...] wiele sławnych dysput w XVI wieku służyło przede wszystkim odgraniczeniu, podkreśleniu własnych poglądów i dyskwalifikacji poglądów przeciwnika. Upadła kultura dialogu. Skutki okazały się zgubne” (W. Beinert, Fundamentalizm a dialog ekumeniczny, w: Dialog Kościołów a tożsamość wyznaniowa, red. Z. Glaeser, S. J. Koza, R. Pierskała, Opole 1994, s. 25). Trzeba więc stopniowo przełamywać wiele mitów i stereotypów wciąż funkcjonujących w społeczeństwie. Por. A. Mińko, Wpro- 
Co więcej, rozbieżności w interpretacji aktu wiary są przyczyną powstawania coraz to nowych Kościołów i wspólnot chrześcijańskich. Często dzieje się tak, że określona grupa chrześcijan „porównuje” swoją wiarę z wiarą innych chrześcijan i dochodzi do wniosku, że trzeba bronić prawdy objawionej przed jej zniekształceniem. Drogą obrony jest odizolowanie prawdziwej wiary od grożących jej niebezpieczeństw. W ten sposób powstają nowe Kościoły, wspólnoty, ruchy, stowarzyszenia i grupy chrześcijańskie, które jak mówią o sobie - chcą uratować prawdziwą wiarę ${ }^{26}$.

Nie mniejsze napięcia pojawiają się także „wewnątrz” poszczególnych Kościołów. Dlatego już apostołowie przypominali o niezawodnym lekarstwie na pokusę rozłamu: miłość w klimacie wzajemnego przebaczenia dla dobra całej wspólnoty. W Liście św. Jakuba Apostoła czytamy: „Jeżeli żywicie w sercach waszych gorzką zazdrość i skłonność do kłótni, to nie przechwalajcie się i nie sprzeciwiajcie się kłamstwem prawdzie. Nie na tym polega zstępująca z góry mądrość, ale mądrość ziemska, zmysłowa i szatańska. Gdzie bowiem zazdrość i żądza sporu, tam też bezład i wszelki występek” (Jk 3, 14-16). Bogusław Seremet zauważa, że „Jakub używa stylu dialogowego [...]. Argumentuje, że wiara w naszego Pana Jezusa Chrystusa nie pozwala na jakiekolwiek formy dyskryminacji wewnątrz wspólnoty" ${ }^{\text {27 }}$.

W świetle nauczania biblijnego widzimy zatem, że wspólne świadectwo nie jest bynajmniej rezygnacją z prawdy. Przeciwnie, prawda ma być u samych podstaw kontynuowania i pogłębiania dialogu wewnątrz danego Kościoła oraz pomiędzy Kościołami (ekumenizm). Wysiłki na rzecz jedności zmierzają do tego, aby przezwyciężyć wszelki rozłam, „aż dojdziemy wszyscy razem do jedności wiary i pełnego poznania Syna Bożego, do człowieka doskonałego, do miary wielkości według Pełni Chrystusa" (Ef 4, 13) ${ }^{28}$.

wadzenie, w: $W$ drodze za Chrystusem. Kościoły chrześcijańskie w Polsce mówią o sobie, red. H. Tranda, M. Patalon, Kraków 2009, s. 9.

${ }^{26}$ Taki „mechanizm” powstawania nowych Kościół i wspólnot nie jest czymś nowym. Świadczy o tym np. historia Jednoty Braci Czeskich. Por. J. Śliziński, Jan Amos Komeński w Polsce, w: Z ufnością w przyszłość. Studia ekumeniczne, red. K. Karski, B. Stahl, A. Wójtowicz, Warszawa 1975, s. 57.

${ }^{27}$ B. Seremet, Dzieje Apostolskie i listy katolickie, Tarnów 2001, s. 48.

${ }^{28}$ Por. P. Kantyka, Jedność Kościoła a jedność w wierze. Od ekumenizmu idealistycznego do ekumenizmu realistycznego?, w: O co chodzi w ekumenizmie? Czym jest dialog? Podstawowe idee Vaticanum II pół wieku później, red. M. Kita (Biblioteka Ekumenii i Dialogu, 37) Kraków 2015, s. 36-37. 
W drodze do tego celu Jezus - dzień po dniu - chce być Przewodnikiem dla wszystkich swoich uczniów: „A oto Ja jestem $\mathrm{z}$ wami przez wszystkie dni, aż do skończenia świata" (Mt 28, 20).

Dialog ekumeniczny to obowiązek i zadanie, a trudności powinny mobilizować do podejmowania jeszcze większych wysiłków, aby przybliżyć godzinę pojednania. To właśnie wiara, o której interpretację także toczy się spór, pomoże „znaleźć rozwiązania”"29. Ona zawsze niejako podpowie tym, którzy biorą udział w dialogu ekumenicznym, że pomimo istniejących różnic, pojednanie jest możliwe, gdyż „wierzyć w Chrystusa znaczy pragnąć jedności; pragnąć zaś jedności znaczy pragnąć Kościoła [...], czyli pragnąć komunii łaski, która odpowiada zamysłowi Ojca, powziętemu przed wszystkimi wiekami" ${ }^{30}$.

Tak właśnie rolę wiary rozumie Kościół katolicki, który swoje zaangażowanie ekumeniczne określa jako „nieodwołalne” ${ }^{\text {”1 }}$. Wie bowiem, że wiara, chociaż sama stanowi temat dialogu ekumenicznego, jest tą rzeczowością, która łączy wszystkich uczniów Chrystusa. Ona sprawia, że ekumeniczna obrona wolności religijnej nie ma nic wspólnego z pragmatycznym kompromisem czy fałszywym irenizmem, które zaciemniają i zacierają prawdę Ewangelii ${ }^{32}$.

Oto dwa pozytywne przykłady ekumenicznej obrony wiary i wolności religijnej, w którą włącza się Kościół katolicki. Pierwszym przykładem jest Światowa Rada Kościołów, z którą Kościół katolicki utrzymuje „owocne relacje ekumeniczne" ${ }^{33}$. Dokumenty przez nią firmowane przenika ufne pragnienie pojednania. Światowa Rada Kościołów to znak usilnego poszukiwania jedności w najważniejszych sprawach. Tematy, które w ramach działalności tego międzynarodowego gremium są podejmowane, można

${ }^{29}$ Jan Paweł II, Encyklika Centesimus annus, 59, w: Jan Paweł II, Encykliki Ojca Świętego Jana Pawła II, t. 2, Kraków 1996, s. 527.

${ }^{30}$ Jan Paweł II, Encyklika Ut unum sint, 9, w: Jan Paweł II, Encykliki Ojca Świętego Jana Pawła II, s. 760-761.

${ }_{31}$ Benedykt xvi, Możecie liczyć na moją dobra wolę. Przemówienie do sekretarza generalnego Światowej Rady Kościołów, 16.06.2005, „L’Osservatore Romano” 2005 nr 9, s. 35.

${ }^{32}$ Por. Niemiecka Konferencja Biskupów, Katolicki katechizm dorosłych: wyznanie wiary Kościoła, Poznań 1987, s. 275; M. Skałdanowski, Tożsamość wyznaniowa: studium ekumeniczne, Lublin 2012, s. 190.

${ }_{33}$ Benedykt xvi, Wasza współpraca pogłębia dialog ekumeniczny. Przemówienie do Mieszanej Grupy Roboczej Kościoła Katolickiego i Światowej Rady Kościołów, 25.01.2008, „L'Osservatore Romano" 2008 nr 3, s. 22. 
uznać za etapy „zdobywania” pełnej komunii wśród chrześcijan, czyli pełnej wspólnoty wiary w Jezusa Chrystusa, przy jednoznacznym szacunku dla wolności religijnej ${ }^{34}$.

Innym przykładem budowania jedności na fundamencie wiary oraz w oparciu o zasadę wolności religijnej jest dialog Kościoła katolickiego z Patriarchatem Ekumenicznym Konstantynopola. W przemówieniu skierowanym do kardynałów, biskupów i pracowników Kurii Rzymskiej (22 grudnia 2007 roku), Benedykt Xvi wspominał swoją podróż apostolską do Turcji, w ramach której miało miejsce spotkanie z ekumenicznym patriarchą Bartłomiejem I. Wydarzenie to stanowi wielki znak nadziei, że „wolność religijna, która odpowiada wewnętrznej naturze wiary i jest uznana w zasadach tureckiej konstytucji, (będzie) coraz pełniej urzeczywistniana w odpowiednich normach prawa, jak również w codziennym życiu Patriarchatu oraz innych wspólnot chrześcijańskich" ${ }^{35}$.

Te i wiele innych przykładów wskazują, że wiara może i powinna być fundamentem dialogu ekumenicznego. To prawda, że skarb wiary wciąż jest narażony na „zewnętrzne” niebezpieczeństwa i ataki ze strony tych, którzy wiarę chrześcijańską ignorują, negują, poniżają i odrzucają. Zagrożeniem są także „wewnętrzne” nieporozumienia, w obrębie samego chrześcijaństwa.

Ewangelizacja jest prowadzona w kontekście „obciążenia”, jakim jest podział między chrześcijanami. Fakt ten osłabia wiarygodność świadectwa wobec świata o zbawczym orędziu Ewangelii. Pomimo jednak tych trudności, trzeba usilnie i niezmordowanie podejmować dialog ekumeniczny, aby bronić wiary i zasady wolności religijnej, pamiętając, że podczas ostatniej wieczerzy Jezus w modlitwie do Ojca połączył zadanie zachowania jedności z owocnością misji, jaką Jego uczniowie mają wypełnić wobec świata: „Nie tylko za nimi proszę, ale i za tymi, którzy dzięki ich słowu będą wierzyć we Mnie; aby wszyscy stanowili jedno, jak Ty, Ojcze, we Mnie, a Ja w Tobie, aby i oni stanowili w Nas jedno, aby świat uwierzył, żeś Ty Mnie posłał" ( $\mathrm{J} 17,20-21)$.

${ }^{34}$ Por. A. A. Napiórkowski, Teologia jedności chrześcijan. Podręcznik ekumenizmu, Kraków 2011, s. 36-45. Pojawiły się już elementy porozumienia między Kościołami i wspólnotami chrześcijańskimi. Przykładem może być kwestia ochrony dzieła stworzenia. Por. I. Czaczkowska, Pomiędzy potopem a tęczą. Ekumeniczne studium integralności stworzenia, Lublin 1998, s. 21.

${ }^{35}$ Benedykt xvi, Otwórzmy się na Boga, by zapanowat Otwórzmy się na Boga, by zapanował pokój. Spotkanie z kardynałami biskupami i pracownikami Kurii Rzymskiej, 22.12.2006, „L'Osservatore Romano” 2007 nr 2, s. 44. 


\section{Zakończenie: „przymus niewiary” motywacją ekumenizmu?}

Na jakim etapie jest dziś dialog ekumeniczny? Czy podziały, które nastąpiły w ciągu dziejów, dotknęły chrześcijaństwo do tego stopnia, że pełna jedność w wierze jest już nie do przywrócenia? A także: Jak pogodzić wspólną wiarę w Chrystusa z podziałami wśród chrześcijan w wielu szczegółowych tematach?

Szukając odpowiedzi na te i podobne pytania, warto przywołać syntezę dokonaną przez Zdzisława J. Kijasa. Autor wskazuje w niej na podwójny wymiar jedności Kościoła: uniwersalny i partykularny. Jego zdaniem „rozróżnienie to pozwala mówić o Kościele Jezusa Chrystusa, który jest jeden i jedyny, w liczbie pojedynczej, jak również w liczbie mnogiej. [...] Nie wszystkie Kościoły i wspólnoty kościelne tworzą jeden Kościół Chrystusowy, ale przeciwnie, jeden Kościół Jezusa Chrystusa obecny jest, w różnym stopniu, w tych Kościołach” ${ }^{36}$. Chociaż „ludzkie wysiłki są zbyt małe”37, istnieje realny postęp na drodze ku jedności. I to jest bardzo ważne we współczesnym świecie, w którym w imię błędnie interpretowanej wolności religijnej często dochodzi do niedopuszczalnego i pełnego wewnętrznej sprzeczności „przymusu niewiary".

Powstaje jednak pytanie: Czy tego rodzaju zjawisko, jakim jest „przymuszanie do niewiary”, może być traktowane jako wyzwanie i motywacja do zintensyfikowania wysiłków w dialogu ekumenicznym? Wydaje się, że tak, chociaż nie w kategoriach motywacji dominującej. Rozważmy tę kwestię w kontekście „spotkania” ekumenizmu i ateizmu.

Od strony teoretycznej ekumenizm i ateizm to dwa, zupełnie różne obszary, poglądy, postawy. W praktyce nie zawsze się jednak o tym pamięta. Zdarza się, że w określonym systemie politycznym władza cywilna bądź „wykorzystuje” ekumenizm dla swych ateistycznych celów ${ }^{38}$, bądź - w imię

${ }^{36}$ Z. J. Kijas, Odpowiedzi na 101 pytań o ekumenizm, Kraków 2004, s. 19. Kościół można postrzegać jako wspólnotę wspólnot. Por. E. Adamiak, Communio sanctorum. Zarys ekumenicznie zorientowanej dogmatycznej teologii świętych obcowania, Poznań 2011, s. 125-128.

37 Ł. Kamykowski, Misja Kościoła a dialog ekumeniczny, w: Dialog ekumeniczny a „missio Ecclesiae”, red. M. Chojnacki, J. Morawa, A. A. Napiórkowski, Kraków 2011, s. 32.

${ }^{38}$ Czesław S. Bartnik wspomina, że po II wojnie światowej w Polsce „władze państwowe i partyjne ateistyczne zaczęły bardzo wspierać ekumenizm w Polsce w nadziei, że rozmyje on i z czasem rozbije doktrynę katolicką, a także odbierze władzę nad nim Prymasowi. Obawa, 
ateizmu - przymusza do niewiary, np. przez zakaz podejmowania wysiłków ekumenicznych ${ }^{39}$. W obu przypadkach uczestnicy dialogu ekumenicznego mają świadomość, że wiara chrześcijańska jest wykorzystywana politycznie. Co więcej, chrześcijanie z różnych Kościołów i wspólnot są postrzegani jako wrogowie państwa, a nie pełnoprawni uczestnicy dialogu społecznego, co nie tylko jest złamaniem zasady wolności religijnej, ale de facto nosi znamiona prześladowania ${ }^{40}$.

A zatem jeśli z ateizmem łączy się „przymus niewiary”, obrona wolności religijnej domaga się odważnego świadectwa ze strony wszystkich wyznawców Chrystusa. Tak to rozumie Kościół katolicki, który m.in. w czasie przygotowania kandydatów do pracy misyjnej podkreśla, że „celem tej formacji jest pozytywne otwarcie formowanego na konfrontację z całą problematyką różnobarwnego pluralizmu, inkulturacji i kontekstualizmu, dialogu międzyreligijnego i współpracy ekumenicznej [...]. Ponadto w przygotowaniu pastoralnym chodzi o zdolność do [...] konfrontacji z sekularyzmem, obojętnością, ateizmem i różnymi systemami ideologicznymi [...]"41.

że wszystkie wyznania przez ekumenizm zjednoczą się przeciwko komunistom szybko ustąpiła, gdyż zorientowano się, że wszystkie wyznania w Polsce są ściśle poddane rządowi, a jedynie Kościół katolicki zachowuje właściwą autonomię" (C. S. Bartnik, Istota chrześcijaństwa, Lublin 2004, s. 116).

39 Co do niweczenia wysiłków ekumenicznych, Bartnik pisze: „Czynnik polityczny zwykle przeszkadza porozumieniu międzywyznaniowemu, a tym bardziej jedności, jak miało to miejsce w krajach o rządach ateistycznych. Gdzie nie ma pełnej wolności religijnej, tam często władze polityczne niweczą wszelki ekumenizm lub utrzymują jedynie fikcję w zamian za różne korzyści wymierne politycznie. W każdym razie ekumenizm wiąże się ściśle z ustrojem Kościoła, ma swój wymiar polityczny i realnie rozwija się słabiej tam właśnie, gdzie nie ma władzy centralnej i gdzie dominuje czynnik polityczny" (C. S. Bartnik, Istota chrześcijaństwa, s. 125).

${ }^{40}$ Nie są to odosobnione przypadki, gdy obrona praw obywatelskich wystawia chrześcijan na prześladowania: „Dowodem tragicznych dziejów i męczeństwa Polski i Polaków w latach osiemdziesiątych są urny z ziemią obficie zbroczoną krwią, zrzeszonych w Nszz «Solidarność», zamordowanych stoczniowców Wybrzeża, robotników Radomia, śląskich górników i duszpasterza ludzi pracy, księdza Jerzego Popiełuszki. «Ojczyzna moja jest głębokim dołem, schyl głowę przed nim, bo w dole tym leżą z umilkłym sercem, przestrzelonym czołem ciała zabrane poległym żołnierzom»" (J. Golonka, Kaplica Pamięci Narodu im. o. Augustyna Kordeckiego na Jasnej Górze, „Jasna Góra” 7 (1989) nr 12, s. 12).

${ }^{41}$ A. Miotk, Wszechstronne przygotowanie misjonarza w xxI wieku, w: Misjologia XXI wieku. W 20 rocznicę śmierci Ojca Feliksa Zapłaty svD - twórcy misjologii w Polsce, red. A. Miotk, Warszawa 2004, s. 164. Otwartość na dialog z takimi kierunkami myślenia, jak ateizm, jest ważny nie tylko dla dialogu ekumenicznego, ale także międzyreligijnego. Antoni Lewek uważa, że „chrześcijanin o wierze dojrzałej [...] jest zdolny przede wszystkim do dialogu ekumenicz- 
Krzysztof Jeżyna wyjaśnia, że „Kościół prowadzi dialog zbawczy ze wszystkimi ludźmi według wskazania Pawła vi, który określił kręgi dialogu zbawienia: dialog ekumeniczny z braćmi odłączonymi, dialog z wyznawcami religii niechrześcijańskich oraz dialog z wszystkimi ludźmi dobrej woli, choćby byli niewierzącymi lub ateistami" ${ }^{42}$. Osobiste świadectwo o słuszności tej praktyki daje Stefan Wilkanowicz, który zwraca uwagę na jeszcze inny aspekt: „Myślę, że ekumenizm bardzo pomaga do nawiązania dialogu nie tylko pomiędzy wierzącymi a ateistami, ale także do naprawy stosunków pomiędzy samymi katolikami, skłóconymi co do «właściwych» sposobów służenia Kościołowi i najlepszych «metod zbawienia świata». Wielkie więc są pożytki z ekumenizmu [...]"43.

Oczywiście, o czym nigdy nie wolno zapominać, „kontakt katolików z braćmi rozłączonymi lub ateistami nie może nigdy prowadzić do indyferentyzmu, fałszywego irenizmu, to jest do wyrzekania się prawdy, do zagubienia jej precyzji lub do utwierdzenia innych w błędzie" ${ }^{44}$. Zjawisko ateizmu można natomiast postrzegać jako jeden z motywów kontynuowania i pogłębiania dialogu ekumenicznego dla obrony zasady wolności religijnej. Dlatego Andrzej A. Napiórkowski umieszcza ateizację na liście ważnych stymulatorów dialogu ekumenicznego ${ }^{45}$. O tym realnym i stymulującym

nego z braćmi protestantami i prawosławnymi, jak i członkami różnych wyznań religijnych. Jest też gotowy do dialogu i konfrontacji ze współczesnym ateizmem. W tym miejscu trudno oprzeć się pytaniu: ilu chrześcijan odznacza się taką właśnie wiarą dojrzałą, otwartą, dynamiczną i zdolną do dialogu z ateizmem?" (A. Lewek, Kaznodziejstwo w służbie wiary, w: W kierunku religijności, red. B. Bejze, Warszawa 1983, s. 128).

${ }^{42}$ K. Jeżyna, Moralne przesłanie nowej ewangelizacji. Wezwanie do odnowy Kościoła i świata, Lublin 2002, s. 103.

43 S. Wilkanowicz, Dlaczego i jak wierzę, Tarnów 1993, s. 86. Wincenty Granat uważa, że „ekumenizm można pojąć i w znaczeniu szerszym, obejmującym wielkie wyznania pozachrześcijańskie: braminizm, buddyzm, mahometanizm, a także religię Izraela, z której przecież wyrosło chrześcijaństwo. Ekumenizm w szerszym znaczeniu może się odnosić nawet do nie należących do żadnej religii jako instytucji, a posiadających jakąś wiarę w Boga i sens religijny świata, czy nawet do ludzi uważających siebie za ateistów” (W. Granat, U podstaw humanizmu chrześcijańskiego, Poznań 1976, s. 247).

${ }^{44}$ A. Drożdż, Wiara - nadzieja - miłość, Tarnów 1993, s. 72. „Ekumeniczna recepcja to nie podpis pod umową, ale budowanie przestrzeni dla komunii” (J. Froniewski, Teologia anamnezy eucharystycznej jako pamiątki uobecniającej Ofiarę Chrystusa i jej implikacje ekumeniczne, Wrocław 2011, s. 317).

45 „Trzeba wskazać na inne jeszcze stymulatory postawy ekumenicznej: zapotrzebowanie na głębokie poczucie jedności rodzaju ludzkiego, powszechne dążenie do współpracy, ko- 
wpływie ateizmu na istnienie i trwanie dialogu ekumenicznego pisał także Alfons J. Skowronek ${ }^{46}$.

Teologowie są zgodni, że ekumenizm ostatecznie nie wypływa z przesłanek ideologicznych ${ }^{47}$. U jego źródeł jest motywacja historiozbawcza, która jednak nie wyklucza innych argumentów, np. o charakterze egzystencjalnym. Alfons Nossol pisze: „Analiza sytuacji we własnej ojczyźnie, w Europie i całym świecie, która odsłoniła wyniszczające chrześcijaństwo procesy sekularyzmu i ateizacji, przy równoczesnym wewnętrznym rozbiciu wspólnoty Chrystusowej, ukazała ekumenizm jako sprawę egzystencjalnie doniosłą dla rozwoju Ewangelii" ${ }^{48}$.

Mając świadomość owego duchowego spustoszenia, jakiego dokonała programowa ateizacja w Europie, Jan Paweł II wzywał właśnie do wspólnego, ekumenicznego świadectwa ${ }^{49}$. Ze swej strony Benedykt Xvi w przemówieniu

nieczność współdziałania chrześcijańskiego w takich dziedzinach, jak: zabezpieczenie pokoju, walka z niesprawiedliwością, demoralizacją i ateizacją, plagami, które stają się groźbą dla świata, jak wojna nuklearna czy katastrofa ekologiczna” (A. A. Napiórkowski, Ekumeniczne implikacje jedności Europy w jej postmodernistycznym kontekście globalizacji, „Sosnowieckie Studia Teologiczne" 5 (2001), s. 47).

46 „Trudno nie zauważyć, iż ekumeniczna świadomość jest dzisiaj bardziej intensywna niż przed trzydziestu laty, a to na skutek globalnych wyzwań nie tylko pod adresem jakiegoś konkretnego Kościoła, lecz wyzwań wymierzonych w chrześcijaństwo jako całość, przede wszystkim ze strony rosnącego sekularyzmu, praktycznego i wojującego ateizmu, w obliczu wzmagającej się krytyki tradycyjnych Kościołów w zderzeniu z nowymi religiami i w obliczu eksplozji sekt, a także rosnących wpływów islamu” (A. J. Skowronek, U progu czy u kresu posoborowej odnowy Kościoła?, „Znak” 1999 nr 1, s. 115).

47 „Nie do przyjęcia jest wzorzec ekumenicznej strategii zmierzającej do zwarcia szeregów chrześcijańskich dla przeciwstawienia się współczesnemu ateizmowi i postępującej sekularyzacji życia. Ekumenizm nie wypływa z przesłanek ideologicznych czy politycznych, lecz wyrasta $\mathrm{z}$ inspiracji biblijnych i teologicznej refleksji nad danymi Objawienia" (A. Skowronek, Cel i zadania ruchu ekumenicznego, w: Ku chrześcijaństwu jutra. Wprowadzenie do ekumenizmu, red. W. Hryniewicz, J. S. Gajek, S. J. Koza, Lublin 1997, s. 38).

${ }^{4}$ A. Nossol, O wspólne świadectwo chrześcijańskie, „Collectanea Theologica” 56 (1986) nr 4, S. 21.

49 „Europa potrzebuje nas wszystkich zebranych solidarnie wokół Chrystusowego Krzyża i Ewangelii. Winniśmy z uwagą czytać znaki czasu. Jezus Chrystus od wszystkich oczekuje świadectwa wiary. Los ewangelizacji łączy się ze świadectwem jedności dawanym przez Kościół, przez chrześcijan. Znakiem tego wspólnego świadectwa jest braterska współpraca na polu ekumenicznym w Polsce" (Jan Paweł II, Nie żałujmy wysiłku na rzecz wielkiego dzieła pojednania, „L'Osservatore Romano” [numer specjalny, Jan Paweł II w Polsce, 31 maja - 10 czerwca 1997], s. 10). 
do biskupów ukraińskich (rok 2007) podobnie zaakcentował, że długie lata panowania ateizmu i komunizmu pozostawiły piętno na żyjących dziś pokoleniach. I są to wyzwania, które stają zwłaszcza przed pasterzami Kościoła w kontekście podejmowanych planów duszpasterskich ${ }^{50}$.

A zatem - podsumujmy - „przymus niewiary”, który tak często łączy się $\mathrm{z}$ ateizmem wojującym, może być uważany za bardzo ważny czynnik pobudzający do jeszcze większej gorliwości w dialogu ekumenicznym. Nie jest to nigdy motyw podstawowy ${ }^{51}$, i nie powinien być traktowany jako najważniejszy punkt odniesienia dla mobilizowania wysiłków ekumenicznych ${ }^{52}$. W dialogu ekumenicznym trzeba go jednak poważnie brać pod uwagę ${ }^{53}$, podejmując wspólne działania - zwłaszcza w obronie wolności religijnej ${ }^{54}$.

\section{Bibliografia}

Adamiak E., Communio sanctorum. Zarys ekumenicznie zorientowanej dogmatycznej teologii świętych obcowania, Poznań 2011.

Anchimiuk J., Problem ekumenizmu dzisiaj, w: Ku chrześcijaństwu jutra. Wprowadzenie do ekumenizmu, red. W. Hryniewicz, J. S. Gajek, S. J. Koza, Lublin 1997, s. $15-17$.

Bartnik C. S., Istota chrześcijaństwa, Lublin 2004.

Beinert W., Fundamentalizm a dialog ekumeniczny, w: Dialog Kościołów a tożsamość wyznaniowa, red. Z. Glaeser, S. J. Koza, R. Pierskała, Opole 1994, s. 15-29.

Benedykt xvi, Afryka jest kontynentem nadziei. Msza św. z okazji przekazania Instrumentum laboris II Specjalnego Zgromadzenia Synodu Biskupów poświęconego Afryce, 19.03.2009, „L'Osservatore Romano” 2009 nr 5, s. 30-32.

5o Por. Benedykt xvi, Zjednoczcie siły, aby możliwe było nowe głoszenie Ewangelii. Przemówienie do biskupów ukraińskich przybyłych z wizytą ad limina Apostolorum, 27.09.2007, „L'Osservatore Romano” 2007 nr 12, s. 17.

${ }^{51}$ Por. A. Skowronek, Cel i zadania ruchu ekumenicznego..., s. 39.

${ }^{2}$ Por. J. Dadaczyński, Poznanie istnienia Boga według ekumenicznego katechizmu dla dorostych „Neues Glaubensbuch”, „Śląskie Studia Historyczno-Teologiczne” 17 (1984), s. 28.

${ }_{53}$ Por. P.-H. Kolvenbach, Ekumenizm wymaga cierpliwości i cierpienia, „Biuletyn Ekumeniczny” 1999 nr 3-4, s. 37; S. Gręś, Rozwój ruchu ekumenicznego. Próba syntezy oparta na materiałach publikowanych $w$ miesięczniku „Znak”, „Studia Paradyskie” 2 (1987), s. 340.

${ }^{54}$ Por. Z. J. Kijas, Odpowiedzi..., s. 37; R. E. Rogowski, Perspektywy rozwoju ruchu ekumenicznego $w$ Polsce, w: Ku chrześcijaństwu jutra. Wprowadzenie do ekumenizmu, red. W. Hryniewicz, J. S. Gajek, S. J. Koza, Lublin 1997, s. 446. 
Benedykt Xvi, Jedność Boga tworzy jedność Kościoła. (Św. Paweł pierwszym teologiem). Audiencja generalna, 15.10.2008, „L'Osservatore Romano” $2008 \mathrm{nr}$ 12, s. 54-56.

Benedykt Xvi, Możecie liczyć na moja dobrą wolę. Przemówienie do sekretarza generalnego Światowej Rady Kościołów, 16.06.2005, „L’Osservatore Romano” $2005 \mathrm{nr}$ 9, s. 35.

Benedykt xvi, Niepokalana Matka pielgrzymującego Kościoła. Homilia w uroczystość Niepokalanego Poczęcia Najświętszej Maryi Panny, 8.12.2005, „L'Osservatore Romano" 2006 nr 2, s. 42-44.

Benedykt XVI, Otwórzmy się na Boga, by zapanował pokój. Spotkanie z kardynałami biskupami i pracownikami Kurii Rzymskiej, 22.12.2006, „L'Osservatore Romano” $2007 \mathrm{nr} 2$, s. 40-44.

Benedykt XVI, Świat potrzebuje Zbawiciela, który narodzit się dla wszystkich. Bożonarodzeniowe orędzie Urbi et Orbi, 25.12.2006, „L'Osservatore Romano” 2007 nr 2, s. 47-48.

Benedykt xvi, Wasza współpraca pogłębia dialog ekumeniczny. Przemówienie do Mieszanej Grupy Roboczej Kościoła Katolickiego i Światowej Rady Kościołów, 25.01.2008, „L'Osservatore Romano” 2008 nr 3, s. 22-23.

Benedykt xvi, Wiara, rozum i uniwersytet - wspomnienia i refleksje. Wykład na uniwersytecie, 12.09.2006 - Ratyzbona, „L'Osservatore Romano” 2006 nr 11, s. 25-29. Benedykt xvi, Zjednoczcie siły, aby możliwe było nowe głoszenie Ewangelii. Przemówienie do biskupów ukraińskich przybyłych z wizytą ad limina Apostolorum, 27.09.2007, „L'Osservatore Romano” 2007 nr 12, s. 17-18.

Czaczkowska I., Pomiędzy potopem a tęcza. Ekumeniczne studium integralności stworzenia, Lublin 1998.

Dadaczyński J., Poznanie istnienia Boga według ekumenicznego katechizmu dla dorostych „Neues Glaubensbuch”, „Śląskie Studia Historyczno-Teologiczne” 17 (1984), s. 27-49.

Drożdż A., Wiara - nadzieja - miłość, Tarnów 1993.

Duquoc Ch., Teologia a życie wewnętrzne, Warszawa 1969, s. 533-540.

Franciszek, Adhortacja apostolska Evangelii gaudium, Kraków, b.d.w.

Froniewski J., Teologia anamnezy eucharystycznej jako pamiątki uobecniającej Ofiare Chrystusa i jej implikacje ekumeniczne, Wrocław 2011.

Golonka J., Kaplica Pamięci Narodu im. o. Augustyna Kordeckiego na Jasnej Górze, „Jasna Góra” 7 (1989) nr 12, s. 11-23.

Granat W., Dogmatyka katolicka, t. 6: Teologiczna wiara, nadzieja i miłość, Lublin 1960. 
Granat W., U podstaw humanizmu chrześcijańskiego, Poznań 1976.

Gręś S., Rozwój ruchu ekumenicznego. Próba syntezy oparta na materiałach publikowanych w miesięczniku „Znak”, „Studia Paradyskie” 2 (1987), s. 337-364.

http://www.ekumenizmiprawo.pl/iv-miedzynarodowa-konferencja-ekumeniczno-prawna.

Jan Paweł II, Cel misyjnej działalności, w: Jan Paweł II, Wierzę w Kościót - jeden, święty, powszechny i apostolski, Libreria Editrice Vaticana 1996, s. 581-584.

Jan Paweł II, Encyklika Centesimus annus, w: Jan Paweł II, Encykliki Ojca Świętego Jana Pawła II, t. 2, Kraków 1996, s. 463-530.

Jan Paweł II, Encyklika Ut unum sint, w: Jan Paweł II, Encykliki Ojca Świętego Jana Pawła II, t. 2, Kraków 1996, s. 755-822.

Jan Paweł II, List [Dokument] L'Eglise catholique o wolności religijnej skierowany do sygnatariuszy Aktu Końcowego Konferencji Bezpieczeństwa i Współpracy w Helsinkach (01.09.1980), w: Jan Paweł II, Wybór listów Ojca Świętego Jana Pawła II, t. 1, Kraków 1997, s. 31-38.

Jan Paweł II, List apostolski Tertio millennio adveniente do biskupów, duchowieństwa i wiernych w związku z przygotowaniem do Jubileuszu Roku 2000, Wrocław 1998. Jan Paweł II, Nie żałujmy wysiłku na rzecz wielkiego dzieła pojednania, „L'Osservatore Romano" (numer specjalny, Jan Paweł II w Polsce, 31 maja-1o czerwca 1997), s. 9-11.

Jan Paweł II, Prezbiter pasterzem wspólnoty, w: Jan Paweł II, Wierzę w Kościót - jeden, święty, powszechny i apostolski, Libreria Editrice Vaticana 1996, s. 285-289.

Jaskóła P., Bóg dla nas. Ekumeniczno-dogmatyczne studium chrystologii Johna Arthura Thomasa Robinsona, Lublin 1986.

Jeżyna K., Moralne przesłanie nowej ewangelizacji. Wezwanie do odnowy Kościoła $i$ świata, Lublin 2002.

Kamykowski Ł., Misja Kościoła a dialog ekumeniczny, w: Dialog ekumeniczny a „missio Ecclesiae", red. M. Chojnacki, J. Morawa, A. A. Napiórkowski, Kraków 2011, s. $11-32$.

Kantyka P., Jedność Kościoła a jedność w wierze. Od ekumenizmu idealistycznego do ekumenizmu realistycznego?, w: O co chodzi w ekumenizmie? Czym jest dialog? Podstawowe idee Vaticanum iI pół wieku później, red. M. Kita (Biblioteka Ekumenii i Dialogu, 37) Kraków 2015, s. 33-43.

Katechizm Kościoła Katolickiego, Poznań 1994.

Kijas Z. J., Odpowiedzi na 101 pytań o ekumenizm, Kraków 2004.

Kolvenbach P.-H., Ekumenizm wymaga cierpliwości i cierpienia, „Biuletyn Ekumeniczny" $1999 \mathrm{nr}$ 3-4, s. 37-38. 
Konferencja Episkopatu Polski, Orędzie biskupów polskich o potrzebie dialogu i tolerancji w warunkach budowy demokracji, Tarnów 1993.

Kostecki R., Tajemnica współżycia z Bogiem. Zagadnienie cnót teologicznych wiary, nadziei i miłości, Kraków 1983.

Krasiński J., Przez wiarę i nadzieję ku cywilizacji miłości, Sandomierz 1987.

Lewek A., Kaznodziejstwo w służbie wiary, w: W kierunku religijności, red. B. Bejze, Warszawa 1983, s. 119-143.

Międzynarodowa Komisja Teologiczna, Moralność chrześcijańska i jej normy (1974), w: Międzynarodowa Komisja Teologiczna, Od wiary do teologii. Dokumenty Międzynarodowej Komisji Teologicznej (1969-1996), red. J. Królikowski, Tarnów 200o, s. 33-54.

Mińko A., Wprowadzenie, w: W drodze za Chrystusem. Kościoły chrześcijańskie w Polsce mówiq o sobie, red. H. Tranda, M. Patalon, Kraków 2009, s. 7-9.

Miotk A., Wszechstronne przygotowanie misjonarza w XXI wieku, w: Misjologia XXI wieku. W 20 rocznicę śmierci Ojca Feliksa Zapłaty svD - twórcy misjologii $w$ Polsce, red. A. Miotk, Warszawa 2004, s. 133-165.

Napiórkowski A. A., Ekumeniczne implikacje jedności Europy w jej postmodernistycznym kontekście globalizacji, „Sosnowieckie Studia Teologiczne” 5 (2001), s. 39-54.

Napiórkowski A. A., Teologia jedności chrześcijan. Podręcznik ekumenizmu, Kraków 2011.

Niemiecka Konferencja Biskupów, Katolicki katechizm dorosłych: wyznanie wiary Kościoła, Poznań 1987.

Nossol A., O wspólne świadectwo chrześcijańskie, „Collectanea Theologica” 56 (1986) nr 4, s. 21-27.

Olejnik S., Dar, wezwanie, odpowiedź. Teologia moralna, t. 4: Podstawowe ukierunkowanie życia chrześcijańskiego, Warszawa 1989.

Orędzie Episkopatu Polski, Do rodziców katolickich, w: Listy pasterskie Episkopatu Polski 1945-1974, Paris 1975, s. 179.

Panuś T., Czynniki wpływające na efektywną katechizację młodzieży, w: Katechizować dzisiaj. Problemy i wyzwania, red. J. Stala, Kielce 2004, s. 211-238.

Paweł vi, Świadectwo życia chrześcijańskiego, w: Będziecie mi świadkami. Paweł VI przemawia do ludzi świeckich, red. E. Weron, Poznań-Warszawa 1975, s. 169-249.

Rogowski R. E., Perspektywy rozwoju ruchu ekumenicznego w Polsce, w: Ku chrześcijaństwu jutra. Wprowadzenie do ekumenizmu, red. W. Hryniewicz, J. S. Gajek, S. J. Koza, Lublin 1997, s. 443-446.

Serce praw człowieka - konferencja o wolności religijnej w 50. rocznicę zakończenia Soboru, „Wiadomości KAI” 2015 nr 45, s. 7-8. 
Seremet B., Dzieje Apostolskie i listy katolickie, Tarnów 2001.

Siemieniewski A., Ruch New Age wśród nowych zjawisk religijnych, w: Postawy duchowe wobec Boga, Kościoła i człowieka, red. M. Chmielewski, Lublin 1995, s. 141-152.

Skałdanowski M., Tożsamość wyznaniowa: studium ekumeniczne, Lublin 2012.

Skowronek A. J., U progu czy u kresu posoborowej odnowy Kościoła?, „Znak” 1999 nr 1, s. 113-124.

Skowronek A., Cel i zadania ruchu ekumenicznego, w: Ku chrześcijaństwu jutra. Wprowadzenie do ekumenizmu, red. W. Hryniewicz, J. S. Gajek, S. J. Koza, Lublin 1997, s. 37-40.

Sobór Watykański II, Deklaracja o wolności religijnej Dignitatis humanae, w: Sobór Watykański Drugi, Konstytucje, dekrety, deklaracje. Tekst łacińsko-polski, Paris 1967, s. 401-419.

Śliziński J., Jan Amos Komeński w Polsce, w: Z ufnościq w przyszłość. Studia ekumeniczne, red. K. Karski, B. Stahl, A. Wójtowicz, Warszawa 1975, s. 57-68.

Wilkanowicz S., Dlaczego i jak wierzę, Tarnów 1993.

Współczesna laicyzacja, w: Listy pasterskie Episkopatu Polski 1945-1974, Paris 1975, s. 261-269.

\section{Streszczenie}

Nauczanie Kościoła i refleksja teologów nie pozostawia wątpliwości co do osobowego charakteru wiary chrześcijańskiej. Wiara jest decyzją rozumną i wolną; decyzją, która nie może być w jakikolwiek sposób wymuszana ani zabraniana. Analiza zawarta w niniejszym studium wskazuje, że dialog ekumeniczny stoi wobec konieczności obrony wiary przed jawnym lub ukrytym łamaniem zasady wolności religijnej. Chodzi o wspólny głos o charakterze ewangelizacyjnym i ekumenicznym. Pomimo różnic, jakie wciąż istnieją w ramach chrześcijaństwa, wszyscy uczniowie Chrystusa winni jednoznacznie opowiadać się za wolnością religijną, dając jednocześnie czytelne świadectwo o wierze jako bezcennym skarbie otrzymanym od Boga.

\section{Słowa kluczowe}

„przymus niewiary”, ateizm, ekumenizm, ewangelizacja, niewiara, wiara, wolność religijna 


\section{Summary}

\section{Present „compulsion of disbelief” as a chalenge for ecumenism}

The Church teaching and reflections made by theologians do not leave any room for doubts concerning the personal character of Christian faith. Faith is a conscious and free decision; decision that cannot be forced, nor forbidden in any way. This study analysis shows that the ecumenical dialogue faces the necessity to defend faith against open or hidden violation of the rule of freedom of religion. This is about common voice that has evangelical and ecumenical character. Despite differences that are still present in Christianity, all Christ's disciples should explicitly stand for the freedom of religion and at the same give an obvious evidence that faith is a priceless treasure received from God.

\section{Keywords}

„compulsion of disbelief”, atheism, ecumenism, evangelisation, disbelief, faith, freedom of religion 